\title{
Physico-Chemical Characteristics and Phytoplankton Abundance of the Lower Niger River, Kogi State, Nigeria
}

\author{
${ }^{1}$ Ali Mohammed Zakariya, ${ }^{2}$ Michael Abiodun Adelanwa and ${ }^{3}$ Yahuza Tanimu \\ ${ }^{1,2,3}$ Department of Biological Sciences, Ahmadu Bello University, Zaria, Nigeria
}

\begin{abstract}
The River Niger serves a multitude of purposes for the Nigerian populace. It is a source of drinking water, hydro-electric power generation, irrigation, transportation and fishing other uses. A segment of the lower Niger River was surveyed for physico-chemical characteristics of water and phytoplankton abundance during two (2) months of dry season and two (2) months of wet season using standard methods. In the five sampling stations surveyed, Surface Water Temperature, Turbidity, Dissolved Oxygen, $\mathrm{PO}_{4}-\mathrm{P}$ and $\mathrm{pH}$ did not statistically significantly vary between the stations $(P>0.05)$, whereas $\mathrm{BOD}$ and $\mathrm{NO}_{3}-\mathrm{N}$ varied statistically significantly between the stations $(P<0.05)$. Phytoplankton abundance showed the following order of abundance: Bacillariophyta > Cholorophyta > Cyanophyta > Chrysophyta > Pyrrophyta. Based on ShannonWeiner diversity index, the water in the 5 stations surveyed is classified to be moderately polluted. The results of this survey has shown that the multitude of users of the Lower Niger River have negatively impacted its water quality.
\end{abstract}

Keywords: River Niger, Water Quality, Phytoplankton

\section{Introduction}

The River Niger (originally called 'egerou n-igerou' by the Tuareg meaning 'river of rivers) is a transboundary river, originating from Guinea, flowing through Mali, Niger, forming the border with Benin and discharging into the Atlantic Ocean in Nigeria [1,2]. The name Nigeria was derived from the name of the River Niger and it is the biggest river in the country which sustains remarkable biological communities. The river harbours 36 families and nearly 250 species of freshwater fish, out of which 20 are found nowhere else on Earth. Eleven (11) of the 18 families of freshwater fish that are endemic to Africa are represented in the Niger River [2].

The River Niger is a source of drinking water, hydro-electric power, irrigation, transportation, fishing among a number of other uses. Human activities have been implicated to impair water quality, sometimes to unacceptable limits [3 and 4].

Phytoplankton are microscopic aquatic plants, occurring as unicellular, colonial or filamentous forms, without any resistance to currents and are free-floating or suspended in the open waters [5].

They are important water quality indicators because of their short life cycles, and ability to respond to environmental changes, hence, their standing crop and species composition indicate the quality of water [6, 7, 8 and 9]. Previous works on the use of phytoplankton as water quality indicators include [10, 11, 12, 13,14 and 15].

This study was carried out to evaluate the impact of human activities on the water quality status of the lower Niger River in Kogi State using physico-chemical characteristics and phytoplankton as indicators.

\section{Materials and Methods}

\subsection{Study Area}

The study was carried out in the portion of the lower River Niger that falls in Lokoja $\left(7^{\circ} 48^{\prime} \mathrm{N}, 7^{\circ} 28^{\prime} \mathrm{N}\right)$ and Ajaoukuta $\left(6^{\circ} 45^{\prime} \mathrm{E}, 6^{\circ} 41^{\prime} \mathrm{E}\right)$ Local Government Areas of Kogi state. The wet season begins mostly in the late April and ends in the late October. Lokoja is the confluence townof the Rivers Niger and Benue. Sampling was carried out in two months of dry season (March and April, 2011) and two months of wet season (May and June, 2011). Water samples were collected from five different sampling stations on the lower Niger River. Two sampling points were selected upstream (before the confluence) namely- RN1 (Kpata) $\left(7^{\circ} 011^{\prime} \mathrm{N}\right.$, $\left.6^{\circ} 012^{\prime} \mathrm{E}\right)$, RN2 (Adankolo) $\left(7^{\circ} 012^{\prime} \mathrm{N}, 6^{\circ} 013^{\prime} \mathrm{E}\right)$, one at the confluence of rivers Niger and Benue $(\mathrm{RN} 3)\left(7^{\circ} 012^{\prime} \mathrm{N}, 6^{\circ} 012^{\prime} \mathrm{E}\right)$ and two downstream (after the confluence) namely- RN4 and RN5 (Ganaja area) $\left(7^{\circ} 013^{\prime} \mathrm{N}, 6^{\circ} 012^{\prime} \mathrm{E}\right.$ and $7^{\circ} 014^{\prime} \mathrm{N}, 6^{\circ} 013^{\prime} \mathrm{E}$ respectively).

Between the confluence and the two sampling stations upstream is a major stream known as "Memeh" that empties into the river. The sampling stations upstream is characterized by heavy human activities as compared to the sampling stations downstream and the stations are located some few meters away from the river bank. 


\subsection{Physico-chemical Parameters}

Physico-chemical parameters of water were analyzed once a month from March 2011 to June 2011. Surface water temperature was measured in situ using a mercury thermometer. $\mathrm{pH}$ was measured using HANNA instrument (pH/Electrical Conductivity/Temperature meter model 210). Dissolved oxygen (DO), Biological Oxygen Demand (BOD), Nitrate-Nitrogen $\left(\mathrm{NO}_{3}-\mathrm{N}\right)$, Turbidity and Phosphate-phosphorus $\left(\mathrm{PO}_{4}-\mathrm{P}\right)$ were determined by methods described by [16].

\subsection{Phytoplankton Collection}

Phytoplankton was collected using conical shape plankton net of $20 \mathrm{~cm}$ diameter with a $50 \mathrm{ml}$ collection vial attached to it [17]. Samples were collected at five sampling points. Phytoplankton was identified by consulting texts by [17] and Perry [18].

\subsection{Analysis of Parameters and Statistical Analysis}

SAS package was used for the Analysis Of Variance (ANOVA) for the physicochemical characteristics and phytoplankton abundance. Means were separated using the Duncan's Multiple Range Test (DMRT). Paleontology Statistics version 18 (PAST) was used to determine the diversity of the phytoplankton between the divisions in each sampling station.

\subsection{Physico-chemical Characteristics}

\section{Results}

The mean surface Water Temperature was $29.35^{\circ} \mathrm{C}$ with a standard deviation of 2.10 . The highest average temperature for the segment of the river studied was $31^{\circ} \mathrm{C}$ while the lowest average temperature was $21^{\circ} \mathrm{C}$ (Table 1). Analysis of variance reveals that there was no statistically significant variation in Water Temperature between sampling stations and between months $(\mathrm{P}>0.05)$ (Tables 2 and 3 ).

A circum-neutral $\mathrm{pH}$ was observed during the study period, with the highest average value of 7.50 and a lowest of 6.78. The mean \pm SD for $\mathrm{pH}$ is $7.25 \pm 0.23$ (Table 1 ). This observed variation was statiscally significant between months $(P<0.05)$ but not between stations $(P>0.05)$ (Tables 2 and 3$)$.

Mean Turbidity was highest in the month of March 101.60 JTU and decreased steadily to June (the last month of the study), with a value of 24.80 JTU. The variations in Turbidity varied statistically significant between months $(\mathrm{P}<0.05)$ and not between the stations $(\mathrm{P}>0.05)$.

The highest $\mathrm{NO}_{3}-\mathrm{N}$ value recorded was $17.5 \mathrm{mg} / \mathrm{L}$ and a lowest of $1.5 \mathrm{mg} / \mathrm{L}$ with a mean $\pm \mathrm{SD}$ of $5.15 \pm$ $4.71 \mathrm{mg} / \mathrm{L}$ (Table 1). Analysis of variance showed a statistically significant variation in the means between the sampling stations $(\mathrm{P}<0.05)$, but not between the months $(\mathrm{P}>0.05)$ (Tables 2 and 3$)$.

The mean DO value observed during the study was $8.2 \mathrm{mg} / \mathrm{L}$ with a SD of $0.55 \mathrm{mg} / \mathrm{L}$. The highest and lowest DO values observed were 9.25 and $7.20 \mathrm{mg} / \mathrm{L}$ respectively (Table 1). Analysis of variance showed that there are no statistically significant variations between the sampling stations as well as between the months $(\mathrm{P}>0.05)$ (Tables 1 and 2).

The BOD had a peak value of $2.5 \mathrm{mg} / \mathrm{L}$, a lowest value of $0.10 \mathrm{mg} / \mathrm{L}$ and a mean $\pm \mathrm{SD}$ of $1.27 \pm 0.76$. Results from ANOVA showed that the observed variations were not significant between months $(\mathrm{P}>0.05)$ but were between sampling stations $(\mathrm{P}<0.05)$.

$\mathrm{PO}_{4}-\mathrm{P}$ showed the highest monthly mean concentration of $2.40 \mathrm{mg} / \mathrm{L}$ in June. This concentration was significantly higher than the concentration in other months $(\mathrm{P}<0.05)$ (Table 2). The highest mean concentration of $1.85 \mathrm{mg} / \mathrm{L}$ recorded at station 5 was not statistically significantly different with the values obtainedat the other sampling stations $(\mathrm{P}>0.05)$ (Table 3$)$.

Table 1: Summary Statistics of Physicochemical Characteristics of the lower River Niger Kogi state

\begin{tabular}{llllll}
\hline Parameters & Units & Mean & SD & Minimum & Maximum \\
\hline Water Tem. & ${ }^{\circ} \mathrm{C}$ & 29.35 & 2.1 & 21 & 31 \\
pH & - & 7.25 & 0.23 & 6.78 & 7.5 \\
Turbidity & JTU & 61.85 & 44.11 & 4.00 & 147 \\
PO $_{4}-\mathbf{P}$ & $\mathrm{mg} / \mathrm{L}$ & 1.49 & 0.76 & 0.33 & 3.3 \\
NO $_{3-\mathbf{N}}$ & $\mathrm{mg} / \mathrm{L}$ & 5.14 & 4.71 & 1.50 & 17.5 \\
DO & $\mathrm{mg} / \mathrm{L}$ & 8.21 & 0.55 & 7.20 & 9.25 \\
BOD & $\mathrm{mg} / \mathrm{L}$ & 1.27 & 0.76 & 0.10 & 2.50 \\
\hline
\end{tabular}


Table 2: Mean values of the physicochemical characteristics at different months on the lower Niger River in Kogi state

\begin{tabular}{|c|c|c|c|c|c|c|c|}
\hline Parameters & $\begin{array}{l}\text { Water } \\
\text { Temperature } \\
\left({ }^{0} \mathrm{C}\right)\end{array}$ & pH & $\begin{array}{l}\text { Turbidity } \\
\text { (JTU) }\end{array}$ & $\begin{array}{l}\text { Dissolved } \\
\text { Oxygen } \\
(\mathrm{mg} / \mathrm{L})\end{array}$ & $\begin{array}{l}\text { Biochemical } \\
\text { Oxygen } \\
\text { Demand } \\
(\mathrm{mg} / \mathrm{L})\end{array}$ & $\begin{array}{l}\mathrm{NO}_{3}-\mathrm{N} \\
(\mathrm{mg} / \mathrm{L})\end{array}$ & $\begin{array}{l}\mathrm{PO}_{4}-\mathbf{P} \\
(\mathrm{mg} / \mathrm{L})\end{array}$ \\
\hline March & $29.40^{\mathrm{a}}$ & $7.42^{\mathrm{a}}$ & $101.60^{\mathrm{a}}$ & $8.34^{\mathrm{a}}$ & $1.49^{\mathrm{a}}$ & $5.00^{\mathrm{a}}$ & $1.53^{b}$ \\
\hline $\begin{array}{l}\text { April } \\
\text { May }\end{array}$ & $\begin{array}{l}28.00^{\mathrm{a}} \\
30.20^{\mathrm{a}}\end{array}$ & $\begin{array}{l}7.40^{\mathrm{a}} \\
7.30^{\mathrm{b}}\end{array}$ & $\begin{array}{l}95.60^{\mathrm{a}} \\
25.40^{\mathrm{b}}\end{array}$ & $\begin{array}{l}8.19^{\mathrm{a}} \\
8.38^{\mathrm{a}}\end{array}$ & $\begin{array}{l}1.20^{\mathrm{a}} \\
1.37^{\mathrm{a}}\end{array}$ & $\begin{array}{l}7.18^{\mathrm{a}} \\
5.36^{\mathrm{a}}\end{array}$ & $\begin{array}{l}1.35^{\mathrm{b}} \\
0.67^{\mathrm{c}}\end{array}$ \\
\hline June & $29.80^{\mathrm{a}}$ & $6.87^{\mathrm{c}}$ & $24.80^{\mathrm{b}}$ & $7.95^{\mathrm{a}}$ & $1.05^{\mathrm{a}}$ & $3.02^{\mathrm{a}}$ & $2.4^{\mathrm{a}}$ \\
\hline
\end{tabular}

Means with different letters in each column are significantly different $(\mathrm{P}<0.05), \mathrm{a}>\mathrm{b}>\mathrm{c}$

Table 3: Mean values of the physicochemical characteristics at the five sampling station on the lower Niger

\begin{tabular}{llllllll} 
Station & $\begin{array}{l}\text { Water } \\
\text { Temperature } \\
\text { (0C) }\end{array}$ & $\mathbf{p H}$ & $\begin{array}{l}\text { Turbidity } \\
\text { (JTU) }\end{array}$ & $\begin{array}{l}\text { Dissolved } \\
\text { Oxygen } \\
\text { (mg/L) }\end{array}$ & $\begin{array}{l}\text { Biochemical } \\
\text { Oxygen } \\
\text { Demand } \\
(\mathbf{m g} / \mathbf{L})\end{array}$ & $\begin{array}{l}\mathbf{N O}^{\mathbf{N}} \mathbf{- N} \\
(\mathbf{m g} / \mathbf{L})\end{array}$ & $\begin{array}{l}\mathbf{P O}_{\mathbf{4}}-\mathbf{P} \\
(\mathbf{m g} / \mathbf{L})\end{array}$ \\
\hline RN1 & $28.25^{\mathrm{a}}$ & $7.32^{\mathrm{a}}$ & $42.75^{\mathrm{a}}$ & $8.73^{\mathrm{a}}$ & $2.24^{\mathrm{a}}$ & $4.65^{\mathrm{b}}$ & $1.10^{\mathrm{a}}$ \\
RN2 & $30.25^{\mathrm{a}}$ & $7.24^{\mathrm{a}}$ & $47.50^{\mathrm{a}}$ & $8.32^{\mathrm{a}}$ & $2.02^{\mathrm{a}}$ & $2.52^{\mathrm{b}}$ & $1.54^{\mathrm{a}}$ \\
RN3 & $30.00^{\mathrm{a}}$ & $7.26^{\mathrm{a}}$ & $90.25^{\mathrm{a}}$ & $8.15^{\mathrm{a}}$ & $0.68^{\mathrm{b}}$ & $2.40^{\mathrm{b}}$ & $1.68^{\mathrm{a}}$ \\
RN4 & $29.25^{\mathrm{a}}$ & $7.22^{\mathrm{a}}$ & $67.25^{\mathrm{a}}$ & $7.97^{\mathrm{a}}$ & $0.74^{\mathrm{b}}$ & $11.87^{\mathrm{a}}$ & $1.27^{\mathrm{a}}$ \\
RN5 & $29.00^{\mathrm{a}}$ & $7.20^{\mathrm{a}}$ & $61.50^{\mathrm{a}}$ & $7.80^{\mathrm{a}}$ & $0.70^{\mathrm{b}}$ & $4.25^{\mathrm{b}}$ & $1.85^{\mathrm{a}}$ \\
\hline
\end{tabular}

Means with different letters in each column are significantly different $(\mathrm{P}<0.05), \mathrm{a}>\mathrm{b}>\mathrm{c}$

Table 3: Phytoplankton species observed in the lower Niger River

\begin{tabular}{|c|c|c|c|}
\hline \multicolumn{2}{|c|}{ Taxa (Relative Abundance) } & Taxa (RelativeAbundance) & Taxa (Relative Abundance) \\
\hline \multicolumn{2}{|c|}{ Bacillariophyta $78 \%$} & Chlorophyta $11.6 \%$ & Cyanophyta $8.2 \%$ \\
\hline Achnanthes clevei & Melosira sp.5 & Actinastrum gracilum & Anabaena sp.1 \\
\hline Achnanthes chilensis & Meuniera membranaceae & Cerasterias staurastroides & Anabaena sp.2 \\
\hline Amphipleura sp 1. & Meuniera sp.1 & Characium limneticum & Anabaena sp.3 \\
\hline Asteronella $\mathrm{sp} .2$ & Meuniera sp.2 & Cosmarium sp. & Aphanocapsa clachista \\
\hline Brachisira viteria & Meridion circulare & Eutetramorus fortii & Aphanocapsa endoplaytica \\
\hline Cylindrotheca closterium & Navicula ambigua & Gonatozygon sp. & Aphasiizomonen flos-aquae \\
\hline Cymbella similis & Navicula gastrum & Haematococcus lacustria & Chrococcus limneticus \\
\hline Cymetopluera solea & Navicula veneta & Mougeotia scalaris & Durvillia antarctica \\
\hline Diatoma actinastroides & Navicula rhynococephala & Mougeotiopsis calospora & Merismopedia $\mathrm{sp} .$. \\
\hline Dictyosolen fragilissmus & Navicula convervaceae & Pediastrum simplex & Microcystis aeruginosa \\
\hline Dictyocha fibula & Navicula sp. 1 & Pediastrum boryanum & Microcystis sp.. \\
\hline Eunotia formica & Navicula sp.2 & Pediastrum duplex & Nodularia spumignea \\
\hline Fragillaria crotonensis & Neidium convectum & Quadrigula closteriopsis & Nodularia $\mathrm{sp} .$. \\
\hline Fragillaria rumpens & Nitzchia desipata & Scenedesmus opoliensis & Oscillatoris tenius \\
\hline Fragillaria sp.1 & Nitzchia closterium & Spirogyra crasa & Oscillatoris princeps \\
\hline Fragillaria $\mathrm{sp} .2$ & Nitzchia filiformes & Spirogyra sp.. & Oscillatoris agardhii \\
\hline Fragillaria sp. 3 & Nitzchia sigmoidea & Staurastrum s sp.1 & \\
\hline Fragillaria sp.4 & Nitzchia denticulata & Staurastrum sp.2 & Pyrrophyta $2.2 \%$ \\
\hline Fragillaria sp.4 & Nitzchia acicularis & Ulothrix subconsticta & Amphidinium sphenoides \\
\hline Guinard delicatula & Nitzchia paradoxa & Ulothrix zonata & Ceratulinia pelagica \\
\hline Leptocylindricus danicus & Nitzchia sigma & Ulothrix cylidricum & Micracanthodium claytonii \\
\hline Martyana martyi & Nitzchia palea & Volvox aureus & \\
\hline Melosira distance & Ophiocytium parculum & Volvox globotar & \\
\hline Melosira granulata & Pinnularia gibba & Volvox sp. & \\
\hline Melosira ikapoensis & Pinnularia viridis & & \\
\hline Melosira italica & Pleurosigma delicatula & & \\
\hline Melosira viriance & Rhoicosphenia curvata & & \\
\hline Melosira sp.1 & Stephanodiscus carconensis & & \\
\hline Melosira sp. 2 & Surirella angustata & & \\
\hline Melosira sp. 3 & Synedra sp. & & \\
\hline Melosira sp.4 & & & \\
\hline
\end{tabular}

\subsection{Phytoplankton Abundance and Diversity}

Diversity indices reveals that Bacillariophyta had the highest number of individuals (189) and taxa (22) at $\mathrm{RN}_{3}$ compared to the values obtained in the other sampling stations. $\mathrm{RN}_{1}$ had the highest value for Shannon 
index (2.53) and Simpson index (0.89) compared to the values obtained at $\mathrm{RN}_{2}, \mathrm{RN}_{4}, \mathrm{RN}_{3}$ and $\mathrm{RN}_{5}$. The lowest dominance was recorded at $\mathrm{RN}_{1}$ (Fig. 1, 2, 3, 4 and 5).

Chlorophyta had the highest dominance at $\mathrm{RN}_{2}$, while Shannon index (1.91) and Simpson index (0.80) were highest at $\mathrm{RN}_{1} . \mathrm{RN}_{3}$ had the highest number of individuals (46) and taxa (12) (Fig. 1, 2, 3, 4 and 5).

Cyanophyta had the highest number of individuals (24), Taxa (8) and Shannon index (1.81) at $\mathrm{RN}_{2}$. While the Simpson index (0.81) was highest at $\mathrm{RN}_{2}$ and $\mathrm{RN}_{4}$ and $\mathrm{RN}_{1}$ had the highest dominance (0.36) (Fig. 1, 2, 3, 4 and 5). For Chrysophyta, the highest number of individuals (12), taxa (3), Simpson index (0.56) and Shannon index (0.96) was obtained at $\mathrm{RN}_{2}$.

\section{Discussion}

The lack of statistically significant variation in water temperature between stations and months observed on the lower Niger River may be due to the reason that the sun is around the tropics during the sampling duration (March-June). Temperatures in the tropics have been reported not vary statistically significantly between the seasons. Similar results have been report by [4 and 11].

The Statistical significant difference in the mean $\mathrm{pH}$ value between the months of the dry season and those of the wet season could be the dissolution of $\mathrm{CO}_{2}$ by rain water thus lowering the $\mathrm{pH}$ during the wet season. The lack of significant statistical variation between station might be due to relatively high alkalinity concentration, which is effective as a buffer to fluctuation of $\mathrm{pH}$ which might be caused by introduction of waste water, photosynthesis and other metabolic processes [10].The hydrogen ion concentration was within the range of inland waters ( $\mathrm{pH} 6.5$ to 8.5), as reported by [19]. [20] reported a $\mathrm{pH}$ range of 6.09 to 8.45 as being ideal for supporting aquatic life including fish.

Thus, the $\mathrm{pH}$ range obtained in this study is within acceptable level of 6.0 to 8.5 for culturing tropical fish species [21 and 22] and or the recommended level for drinking water [23]. The statistically significant variation in the mean turbidity between the months of the dry season and those of the wet season may be attributed to introduction of silt into the river by rain water. The lack of statistical significant variation between stations could be due to the mixing of the fast flowing water as it moves downstream. High turbidity has a corresponding low primary productivity, because urbidity reduces the amount of light penetration which in turn reduces photosynthesis and hence primary productivity [16 and 24].

The mean values of $\mathrm{PO}_{4}-\mathrm{P}$ were found to be above expected concentration range of natural unpolluted waters of $0.090 \mathrm{mg} / \mathrm{L}$ [25]. Land use around riverine areas in Nigeria is predominantly for farming [26]; this could be a possible explanation for the high levels of $\mathrm{PO}_{4}-\mathrm{P}$ that may result from run-offs during rainy season as observed in this study. The high mean values of $\mathrm{PO}_{4}-\mathrm{P}$ in the months of March and April could be due to concentration effects because of reduced water volume; this corresponds to the work of [27]. The high mean values could also be due to lower water hardness thus, less co-precipitation of phosphate with calcium carbonate, a phenomenon that has often been reported to occur in many fresh water lakes [28 and 29].

The mean values for $\mathrm{NO}_{3}-\mathrm{N}$ were also found to be above expected concentration range of natural unpolluted waters of $0.1 \mathrm{mg} / \mathrm{L}$ [25]. High nitrate levels (> 1mg/L) are not good for aquatic life (Johnson et al., 2000). The high level of nitrate observed is in line with the findings of [30], who concluded that nitrate are usually built up during dry seasons and that high levels of nitrates are only observed during early rainy season which correspond to the period of the research work. The statistical significantly higher concentration of $\mathrm{NO}_{3}-\mathrm{N}$ in station 4 in comparison to the other stations might have been due to human activities such as irrigation near the river, discharge of domestic sewage and other organic waste material into the river at that station. The mean values for $\mathrm{NO}_{3}-\mathrm{N}$ was observed to be below the maximum permissible limit of $50 \mathrm{mg} / \mathrm{L}$ for drinking water by the WHO.

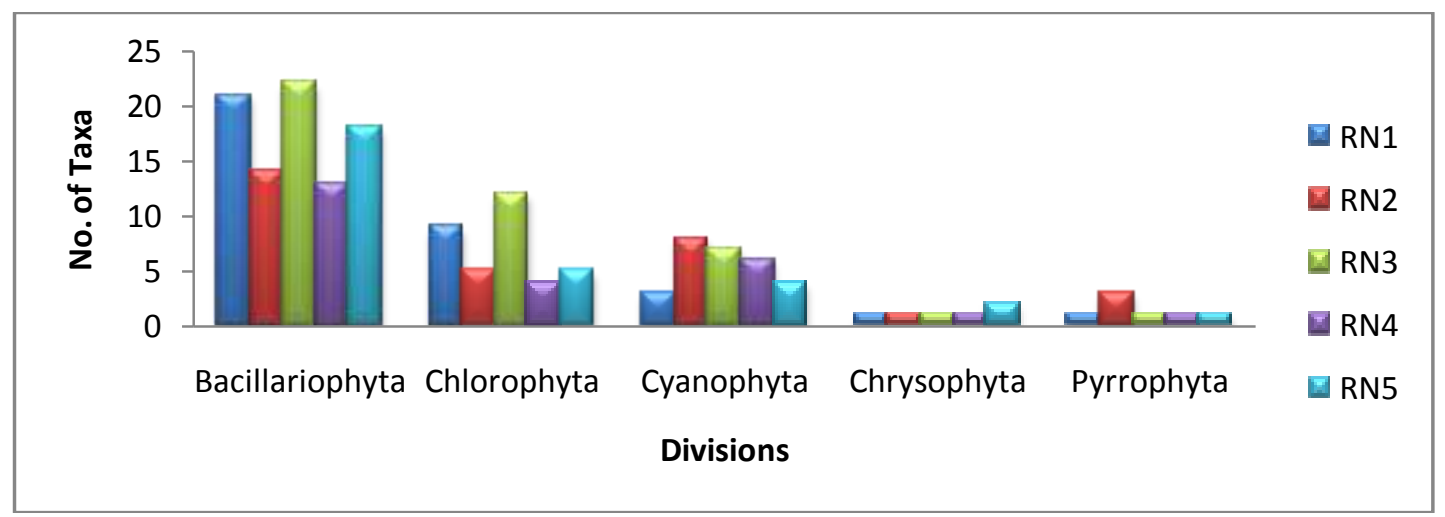

Fig.1: Number of Taxa of Algal Divisions in the lower Niger River 


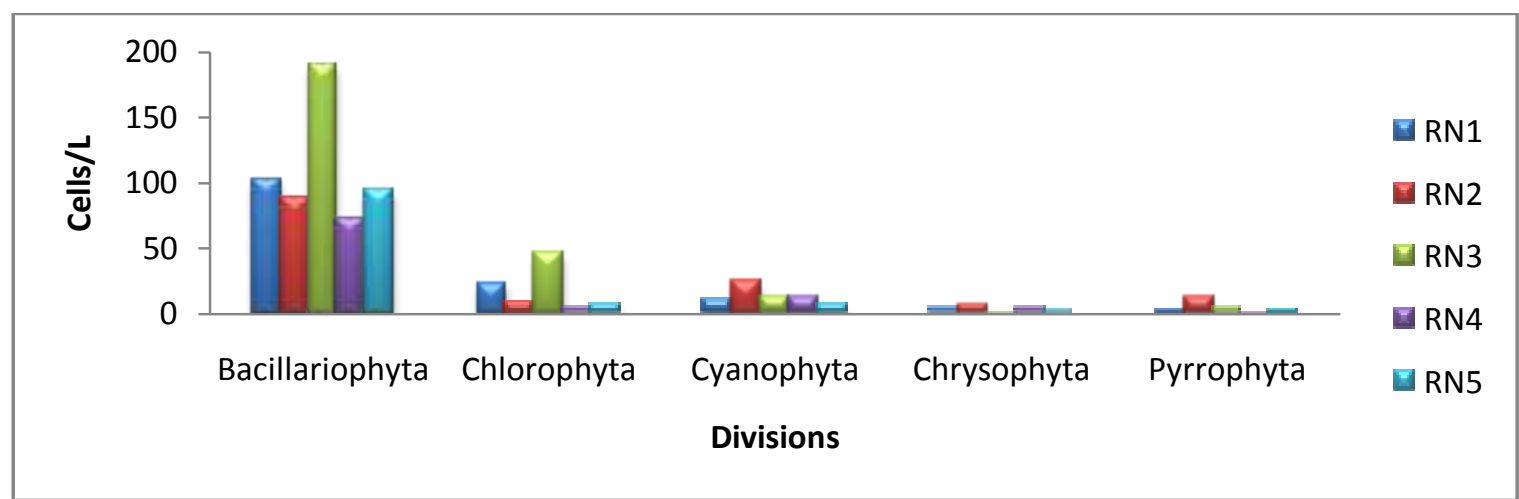

Fig.2: Phytoplankton abundance (number of cells/L) in the lower Niger River

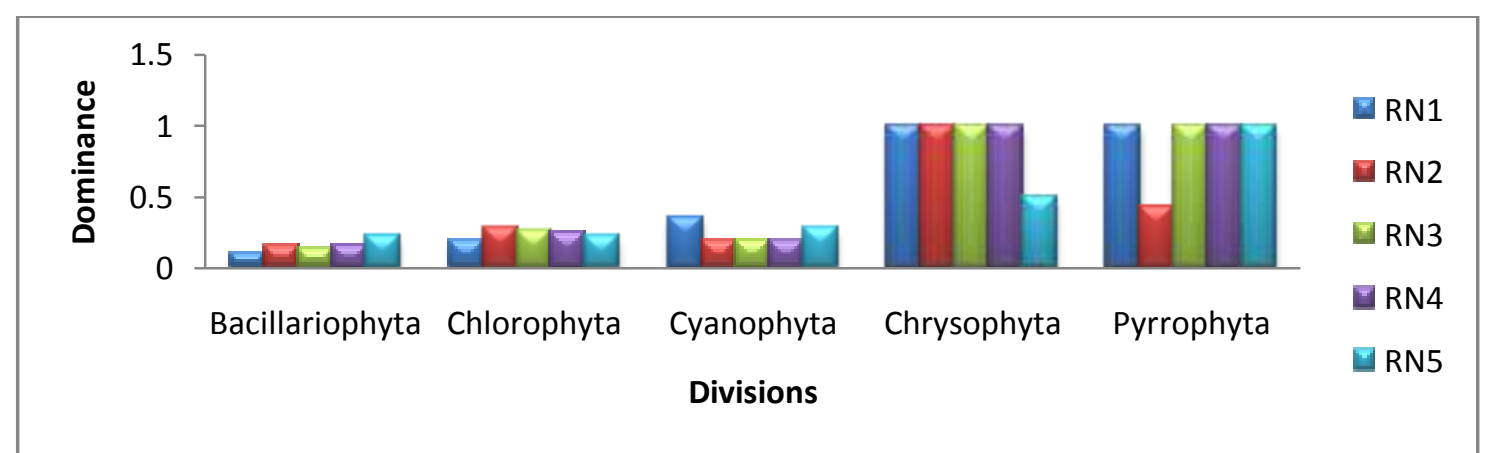

Fig.3: Dominance of Algal Divisions in the lower Niger River

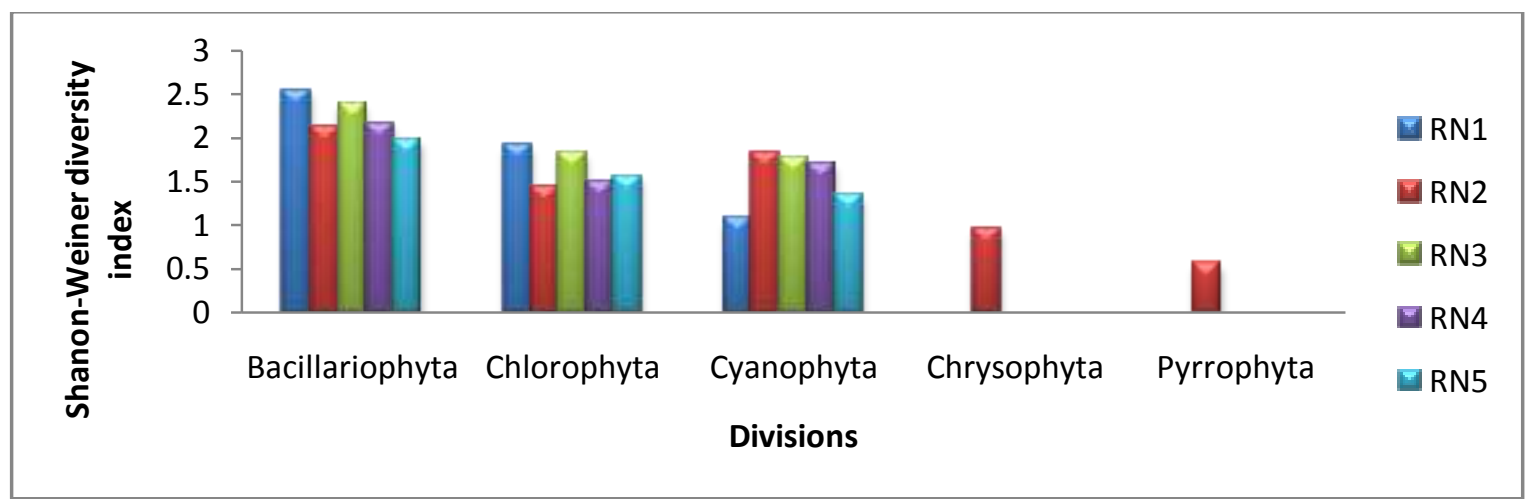

Fig.4: Shannon-Weiner diversity index of Algal Divisions in the lower Niger River

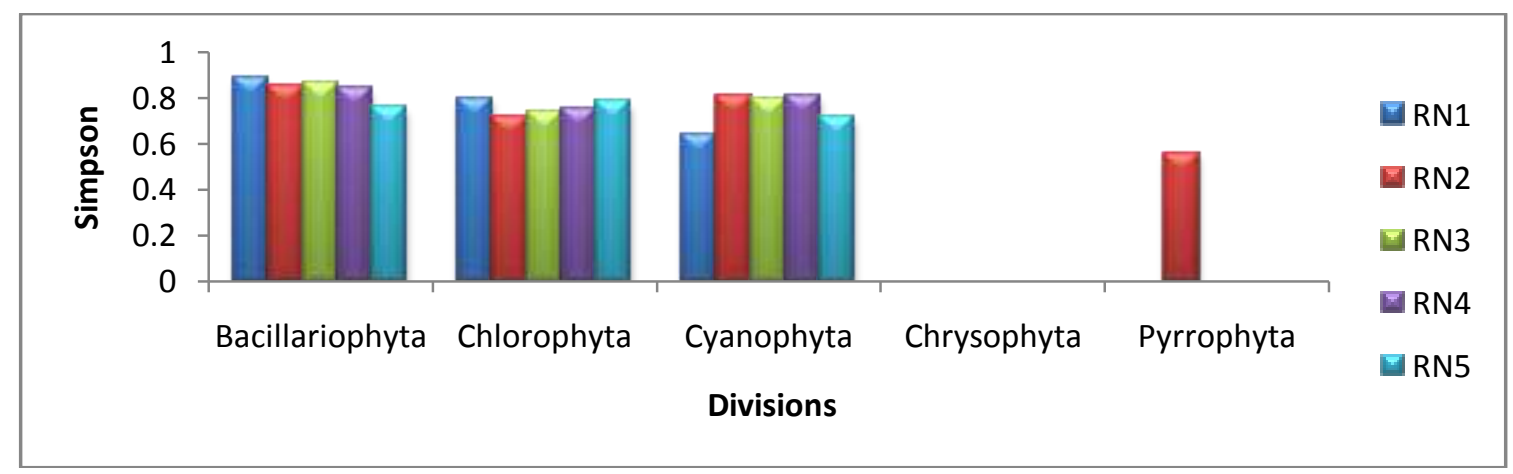

Fig.5: Simpson's index (Evenness) of Algal Divisions in the lower Niger River

Dissolved oxygen in water is an important factor determining the occurrence and abundance of aquatic organisms, because for all the aquatic aerobes, oxygen is pre-requisite for life, thus the more the oxygen available, the more the organisms are found [31]. [23] reported that the amount of DO in water depends on the 
source, temperature, chemical and biological process taking place in a water body. The observed means of DO in the lower Niger River corresponds to the study made by [32].

The high means of DO might be due to abundant oxygen contributed by plants during photosynthetic activity, which contributed in oxygenating the water column and at the same time reducing respiration by aquatic organism and decomposition process at the river bottom [33]. The DO concentration was found to be within the $5 \mathrm{mg} / \mathrm{L}$ to $9 \mathrm{mg} / \mathrm{L}$ limit for drinking water [25].

The mean BOD values of stations 1 and 2 of the lower Niger River were above $2 \mathrm{mg} / \mathrm{L}$ and their statistically significant difference with the three other stations downstream may be attributed to the observed human activities such as washing, dumping of refuse and sewage into the river channel. Based on classification of aquatic bodies, unpolluted (BOD $<1.0 \mathrm{mg} / \mathrm{L}$ ), moderately polluted (BOD $<10.0 \mathrm{mg} / \mathrm{L}$ ) and heavily polluted $(\mathrm{BOD}>10.0 \mathrm{mg} / \mathrm{L}$ ) [34 and 35]. BOD above $1 \mathrm{mg} / \mathrm{L}$ is associated with waste water contamination [25].

Bacillariophyta have been reported by many authors to be dorminat in the phytoplankton composition as it is in the present study $[19,36,37$, and 39]. Chlorophyta was the second group after Bacillariophyta in the number of identified species, these result also agree with study on Grand River in Oklahoma by [39 and 40]. It is also in agreement with other studies in Iraq [19 and 41]. Cyanophyta was present by 65 individual most of which were recorded in the month of June, these result corresponds to other studies [42 and 43].

The maximum occurrence of phytoplankton was in (May, 2011) and then decreased. This was also observed in temperate region [19 and 44]. And the maximum number of species was recorded at $\mathrm{RN}_{3}$ in the month of March, 2011. This may be due to available nutrients and other physical and chemical factors which promote growth of phytoplankton. While the minimum total number of phytoplankton species was recorded at $\mathrm{RN}_{4}$ which might be due to domestic discharge, effluents from run-off that empty into the river, this corresponds to the work of [39]. The differences in number of taxa and number of individuals between sampling stations for each class of phytoplankton may be due differences in temperatures and $\mathrm{pH}$ as different species obtain nutrition at different $\mathrm{pH}$ and temperatures.

[45] have suggested a relationship between species diversity and pollution status of aquatic system and classified as follows; $>3=$ Clean water, $1-3=$ moderately-polluted $<1=$ Heavily polluted. Based on this classification, the lower Niger River in Kogi state is moderately polluted for Bacillariophyta, Chlorophyta and Cyanophyta but heavily polluted for Chrysophyta and Pyrrophyta. A similar classification was also used by [10 and 46]. Simpson index gives the evenness of species distribution; the higher evenness in species distribution for Bacillariophyta, Chlorophyta and Cyanophyta may be an indication that the water quality was better to support the growth of most of the species observed. Similar classification was also used by [10].

\section{Conclusion}

The activities around the catchment of the Niger River have significant effect on the water quality as indicated by the variations in physicochemical characteristics and phytoplankton diversity and abundance.

\section{References}

[1] M. Goulden, and R. Few, Climate change, water and conflict in the Niger River Basin, International Alert and University of East Anglia, 2011.

[2] World Wide Fund for Nature. The river Niger, River of Rivers [online], 1986, http://assets.panda.org/downloads/Niger.pdf. (accessed November, 14, 2012).

[3] Oyema, I.C., The Phytoplankton Composition, Abundance and Temporal Variation of a Polluted Estuarine Creek in Lagos, Nigeria, Turk. J. F. Aq. Sci., 7 (2007) 89-96.

[4] A. M. Chia, S. P. Bako, S. Alonge and A. K. Adamu, Records of Diatoms and Physicochemical Parameters of Seasonal Ponds in Zaria-Nigeria, W. Afr. J. App. Eco., 18 (2011) 79-93.

[5] F. M. Hassan and H. A. Al Saadi, Seasonal variations on the phytoplankton in Alwnd River. Journal of College Education For women, University of Baghdad, 6 (2) (1995), 55.

[6] M. T. Dokulil, Algae as ecological bio-indicators, in: B.A. Markert, A.M. Breure, H.G. Zechmeister, BIOINDICATORS AND BIOMONITORS, Elsevier Science Ltd, New York, 2003, pp. 285-327.

[7] Leelahakriengkrai, P. and Peerapornpisal, Y., Diversity of Benthic Diatoms and Water Quality of the Ping River, Northern Thailand, Environment Asia, 3(1) (2010) 82-94.

[8] R. T. Abagai, F. A. Tiseer, M. L. Balarabe, Y. Tanimu, \& D. Tanko, Seasonal Survey of Phytoplankton as Biondicators of Water Quality in the Streams of Kagoro Forest, Kaduna State, Northern Nigeria, in: International Symposium on Environmental Science and Technology, Dongguan, Guangdong Province, China, 2011.

[9] F. A. Tiseer, Y. Tanimu and A. M. Chia, Survey of Macrovegetation and Water Chemistry of Samaru Stream, Zaria, Nigeria, Res. J. Env. Sci. 2 (2008) 393-400.

[10] Y. Tanimu, S.P. Bako, J. A. Adakole, and J. Tanimu, Phytoplankton as Bioindicators of Water Quality in Saminaka Reservoir, Northern Nigeria, in: International Symposium on Environmental Science and Technology, Dongguan, Guangdong Province, China, 2011.

[11] Y. Tanimu, S.P. Bako, J. A. Adakole, Effects of domestic waste water on water quality of three reservoirs supplying drinking water in kaduna state-Northern Nigeria, Waste water-evaluation and management. Intech., Rijeka, Croatia, 2011, pp. 269-282

[12] M.O. Kadiri, Phytoplankton Flora and Physicochemical attributes of some waters in the Eastern Niger-Delta area of Nigeria. Nigerian Journal of Botany, 19(2) (2006) 188-200.[13] Y. Hossain et al., A preliminary observation on water quality and plankton of an earthen fish pond in Bangladesh: Recommendations for future studies. Pakistan Journal of Bilogical Sciences, 10 (6) (2007) 868873 . 
[14] L.H. Sipauba-Tavares, A.R.V. Donadon and R.N. Milan, Water Quality and Plankton Populations in an Earthen Polyculture Pond, Braz. J.Biol., 71(4) (2011) 845-855.

[15] P. Leelahakriengkrai, S. Pruetiworanan and Y. Peerapornpisal, diversity of Benthic Diatoms and Macroalgae and Water Quality in the River Passing Chiang Rai Province, Thailand, KKU Sci. J. 37 (2009) 143-152.

[16] APHA, Standard Methods for the Analysis of Water and Wastewater. American Public Health Association, New York, (1998) pp. 1287.

[17] R. Perry, A Guide to the marine plankton of southern California [online] (2003), http://www.msc.ucla.edu/oceanglobe, (accessed November, 10, 2010].

[18] G.W.Prescott, The Fresh water Algae, WMC Brown Company Publishers Dubugue,

IOWA, 1977, pp. 1- 212.

[19] S.E. Antoine and H.A. AI-Saadi, Limnological studies on the polluted Ashar Canal at Basra (Iraq). In: Reveges hydrobiologia 67 (1982) 405-418.

[20] C.E. Boyd and F.R. Lichtkoppler, Water quality management in pond fish Culture, Research and Development Series, 22 (1979) $1-30$.

[21] M. Huett, Text Book of Fish Culture, Breeding and cultivation of fish, $2^{\text {nd }}$ edition, News Book Publ. University Press, Cambridge, 1977 , pp. 438.

[22] Ibrahim, S. and Abdullahi, B.A., A Survey of Phytoplankton and Evaluation of some Physicochemical Properties of Challawa River, Kano State, Nigeria. Best Journal, 6(1) (2009) 76-82.

[23] World Health Organisation, Guidelines for drinking water Quality (2ed) (adendum to vol.1), Recomendations. WHO Press, Geneva Switzerland, 2006, p. 595.

[24] United States Environmental Protection Agency, Volunteer Lake monitoring: EPA 440/4-91-002.U.S. Government Protection Agency Washington DC, 1991.

[25] UNESCO, WHO,UNEP, Water quality assessment- A guide to the use of biota, sediments and water in environmental mornitoring, E and FN Spon. Cambridge, Great Britain, 1996.

[26] O.K. Adeyemo, O.A. Adedokun, R.K. Yusuf and E.A. Adeleye, Seasonal changes in Physico-chemical parameters and nutrient load of sediments in Ibadan city, Nigeria. Global NEST Journal, 10, (3) (2008) 326-336.

[27] B.U. Ibrahim, J. Auta and J.K. Balogun, An assessment of physico-chemical parameters of kontagora reservoir, Niger state, Nigeria. Bayero Journal of Pure and Applied Sciences, 2(1) (2009) 64 - 69.

[28] W.A. House, The prediction of phosphate co-precipitation with calcite in fresh waters. Water Research, 24 (1990) 1017-1023.

[29] J. Heleen, L. Danen - Louwerse and C. Monique, Co-precipitation of phosphate with calcium carbonate in Lake Velume. Water Research 29(7) (1995) 1781-1785.

[30] S. Wolfhard and B. Reinhard, The heterogeneity of runoff and its significance for water quality problems, Hydrological SciencesJournal—des Sciences Hydrologiques, 43 (1998) 103-113.

[31] F.S. Conte and J.S. Cubbage, Phytoplankton and Recreational Ponds, Western Regional Aquaculture Center 5(105) (2001) 1-6.

[32] S. Kegley and J. Andrew, The chemistry of water, Sausalito, GA: University Science Books [online], (1998), http//www.ci.federalway.wa.us/main.asp (accessed September, 13, 2012).

[33] N.F. Olele and J.K. Ekelemu, Physicochemical and periphyton/phytoplankton study of Onah Lake, Asaba, Nigeria. African Journal of Gen. Agric. 4(3) (2008) 183-193.

[34] D. Maria, Sewage treatment in hot climate, John Wiley and Sons, Toronto, 1983.

[35] J.A Adakole, J.K. Balogun and F.A. Lawal, Water Quality Impacts Assessment Associated with an Urban Stream in Zaria, Nigeria, NISEB Journal 2 (3) (2002) 195- 203.

[36] R. A. Hadi, A. A. Al-Saboonchi and A.K. Haroon, Phytoplankton ecology in the waters between Shatt A-Arab and Shatt Al-Hilal, Nova Hedwigia, 39 (1984) 513

[37] S. Polat and E. Sarihan, Seasonal changes in the phytoplankton of the Northeastern Mediterranean (Bay of Iskenderum), Turkish Journal of Botany, 24 (2000) 1-12.

[38] S. Polat and A. Aka, Total and size fractionated phytoplankton biomass off Karatas, northeastern Mediterranean coast of turkey. Journal of Black Sea/ Mediteranean Environment, 13 (2007) 191-202

[39] M. H. Fikrat, F. K. Nuha and H. H. Falah, Effect of Chemical and Physical Properties of River Water in Shatt Al-Hilla on Phytoplankton Communities. E-Journal of Chemistry, 5(2) (2008) 323-330.

[40] L.A. Pfiester, R. Lynch and T. L. Wright, Species composition and diversity of Phytoplankton in the grand River dam area Oklahoma, Proceedings of the Oklahoma Academy of. Science, 60 (1980) 63-68.

[41] A.Y. Al-Handal, S. A. Al-Assa and M. A. Al-Mukhtar, Journal of Marine Science Center University. Of Basrah, , 4 (1) (1989), 67.

[42] J. L. Gross and L. A. Pfiester, Blue-green Algae of lake thunderbird. Proceedings of the Oklahoma Academy of Science, 68 (1988) $39-44$.

[43] Cronberg, G., Annadotter, H. and L. A. Lawton, The Occurrence of toxic blue-green algae in Lake Ringsjon Southern Sweden despite nutrient reduction and fish biomanipulation, Hydrobiologia, 404 (1) (1999) 123-129.

[44] A. B. Whitten, Algae, In: Whitten, A B Ed. River Ecology. Blackwell, Oxford, 1975, pp. 81-105.

[45] J.L. Wilm and T.C. Dorris, Species Diversity of Benthic Macroinvertebrates. In: A Stream Receiving Domestic and Oil Refinery Effluents. In: Islam, S.M. Phytoplankton diversity index with reference to mucalinda serovar Bodh-Gaya, 12th World Lack Conference., Taal, India, 2007.

[46] S.A. Shehata, S.A. Badr, G. H. Ali, M.M. Ghazy, A.K. Moawad and S.Z. Wahba, Assessment of Nile Water Quality via Phytoplankton changes and Toxicity Bioassay Test, Journal of Applied Sciences, 5(12)(2009)2083-2095. 